\section{An Alternate-Furrow System for Seeding Northern Colorado Rangeland $^{1}$}

\section{WILLIAM J. MCGINNIES}

\begin{abstract}
Range Scientist, Plant Science Research Division, Agricultural Research Service, U.S. Department of Agriculture, Fort Collins, Colorado.
\end{abstract}

\section{Highlight}

The most successful method for seeding cool-season grasses on northern Colorado rangelands has been to plant with a drill in the spring on a smooth, fallowed seedbed. However, wind erosion may destroy a level-drilled seeding. Planting in deep furrows has resulted in poorer stands, but the deep-furrows appear to be necessary for control of wind erosion. A system is proposed for alternating deepfurrow drilling with level-drilling on the beds between the furrows in order to combine the erosion control benefits on the deep-furrows with the better stand establishment characteristics of the level-drilled planting.

When several range seeding methods were evaluated in northern Colorado, drill-planting on fallowed soil consistently produced the best stands (Bement et al., 1965). During the past 15 years, I have planted more than 75 experiments in northcentral Colorado, and have observed many others. In general, the most consistent success has resulted from using the following planting procedures:

1. Fallow the area to be seeded and prepare a firm seedbed.

2. Plant before or early in the period of highest precipitation (April and May).

3. Control wind and water erosion with cultural treatments and strip planting.

Furrows of various sizes and shapes are commonly used to control erosion on exposed soil. Planting in the bottom of a furrow (deep-furrow seeding) is an accepted way of combining erosion control with the seeding operation, and deep-furrow seeding is the usual method of planting small grains in the fall in northern Colorado. In central Utah, deep furrows produced better stands of crested wheatgrass than did drill-planting (McGinnies, 1959), but in northern Utah there was no difference between furrows and level planting (Hull, 1970).

When I have seeded range grasses in northern Colorado in the spring, stands obtained from level

\footnotetext{
${ }^{1}$ A contribution of Plant Science Research Division, Agricultural Research Service, U.S. Department of Agriculture, and the Colorado Agricultural Experiment Station. Published with the approval of the Director of the Colorado Agricultural Experiment Station as Scientific Series Paper No. 1702. Received for publication December 31, 1971.
}

drill-planting have generally been better than from deep-furrow planting (unpublished data). However, there were several cases where heavy winds destroyed the level-drilled seeding before the seedlings became established.

To prevent wind erosion in small-plot studies and retain the advantages of level seeding, furrows have been cut between the seeded rows in most small-plot studies I have planted since 1963. These small furrows (3 to 4 inches deep) have effectively prevented wind "blow-outs" and appeared to reduce water erosion. The use of furrows between rows requires that the seeded rows be at least 18 , and preferably 24 inches apart; this is a wider row spacing than is generally desirable for most range seeding. The distance between rows in the seeded stand could be reduced if grass could be established both in the furrows and on the level beds between the furrows. The following study reports an evaluation of level drilling and alternating level and deep-furrow rows.

\section{Methods}

Plantings were made 1967 through 1970 at Fort Collins Experimental Range, 10 miles north of Fort Collins, Colorado; and 1968 through 1970 at Central Plains Experimental Range (CPER), 12 milcs northeast of Nunn, Colorado. Precipitation at the Fort Collins site is approximately 15 inches and the soil is a Larimer gravelly loam; at CPER, precipitation averages 12 inches and the soil is a Vona sandy loam. The plot areas were plowed in the summer of the year before planting. In early spring, the plots were smoothed and cultipacked. Individual plots measured 11 by 25 feet. Two plantings were made at each seeding date at each location. Crested wheatgrass (Agropyron desertorum (Fisch. ex Link) Schult.) and Russian wildrye (Elymus junceus Fisch.) were planted on the dates shown in Table 1.

The two planting treatments were (1) level-drilled and, (2) alternating rows level-drilled and deep-furrow drilled (this treatment is called "alternate-furrow" in this paper). In the level-drilled (control) plots, drill-rows were planted 12 inches apart. In the alternate furrow treatment, rows were first level-drilled with rows 24 inches apart. Then, deep-furrow rows, with furrows approximately 3 inches deep, were planted midway between the level-drilled rows, and seed was planted in the bottom of the furrow. Thus, the final configuration was an alternation of deep-furrow rows and level-drilled rows on the beds between the deepfurrow rows; the final row spacing was 12 inches. All seeding was done with a hand-pushed cone-type seeder at a 3/4-inch planting depth and at a seeding rate of 25 seeds per foot of row ( $6 \mathrm{lb}$./acre).

The plots were kept relatively free of weeds with selective herbicides and by occasional hand-weeding. Rabbits and large herbivores were excluded, but small rodents were sometimes found in the plot area.

Seedlings were counted in early September of the year seeded. Seedling counts represent establishment, rather than just emergence, because previous studies indicated that there is almost no loss of plants between September and the following spring. 
Table 1. Number of seedlings per foot of seeded row counted in September of the year of seeding.

\begin{tabular}{|c|c|c|c|c|}
\hline \multirow[b]{3}{*}{$\begin{array}{c}\text { Location, species } \\
\text { and } \\
\text { seeding date }\end{array}$} & \multicolumn{4}{|c|}{ Treatment } \\
\hline & & \multicolumn{3}{|c|}{ Alternate furrow } \\
\hline & $\begin{array}{l}\text { Level-drill } \\
\text { (control) }\end{array}$ & $\begin{array}{l}\text { Level } \\
\text { rows }\end{array}$ & $\begin{array}{l}\text { Deep- } \\
\text { furrow } \\
\text { rows }\end{array}$ & Average \\
\hline
\end{tabular}

Fort Collins

Crested wheatgrass

$\begin{array}{lllll}\text { April 7, 1967 } & 4.7 & 5.3 & 2.6 & 4.0 \\ \text { April 10, 1968 } & 3.0 & 3.7 & 2.4 & 3.0 \\ \text { May 2, 1968 } & 6.2 & 6.3 & 3.6 & 5.0 \\ \text { April 18, 1969 } & 7.0 & 6.8 & 3.9 & 5.4 \\ \text { April 13, 1970 } & 6.2 & 5.8 & 5.7 & 5.8 \\ \text { Russian wildrye } & & & & \\ \text { April 18, 1969 } & 9.2 & 8.5 & 5.5 & 7.0 \\ \text { April 13, 1970 } & 7.1 & 6.6 & 5.6 & 6.1\end{array}$

CPER I

Crested wheatgrass

$\begin{array}{lrrrr}\text { April 15, 1968 } & 6.9 & 6.8 & 3.0 & 4.9 \\ \text { April 30, 1968 } & 7.2 & 8.1 & 4.0 & 6.0 \\ \text { April 28, 1969 } & 8.6 & 11.2 & 5.6 & 8.4 \\ \text { April 16, 1970 } & 4.7 & 3.7 & 1.3 & 2.5 \\ \text { May 12, 1970 } & 6.7 & 8.1 & 5.7 & 6.9 \\ \text { Russian wildryc } & & & & \\ \text { April 28, 1969 } & 4.3 & 3.6 & 1.2 & 2.4 \\ \text { April 16, 1970 } & 2.8 & 2.6 & .6 & 1.6 \\ \text { May 12, 1970 } & 4.0 & 3.6 & 2.8 & 3.2 \\ & & & & \\ \text { rage } & 5.9 & 6.0 & 3.6 & 4.8\end{array}$

${ }^{1}$ Central Plains Experimental Range, Nunn, Colorado.

\section{Results}

The average number of seedlings per foot of row in the level-drilled control plots did not differ significantly from the average number of seedlings per foot in the level-drilled rows in the alternatefurrow plots (Table 1). However, the number of seedlings per foot of row in the deep-furrows was significantly lower than the number in the leveldrilled rows between the furrows or in the leveldrilled plots. The average number of seedlings in the alternate-furrow plots (the average of numbers of seedlings in deep-furrow and level-drilled rows) was 4.8 seedlings $/ \mathrm{ft}^{2}$ and was significantly less than the average of 5.9 seedlings in the level-drilled plots.

During the period covered by this study, no planting was seriously damaged by wind or water erosion. The small size of the planted areas probably prevented the wind getting a sufficient "sweep" at the plots to blow out any of the nonfurrowed plots. However, the furrows were always partially or, more commonly, completely filled with soil by the end of the season; this resulted from movement of soil by both wind and water. When wind or rain storms occurred soon after planting, soil was deposited in the furrows, and the seed in the deep-furrows was sometimes buried to a total depth of $1^{1 / 2}$ to 2 inches. Other studies I conducted concurrently (unpublished) indicated that there was a substantial reduction in seedling numbers when seed is $1 \frac{1 / 2}{2}$ to 2 inches deep as compared to seed planted $1 / 2$ to 1 inch deep. Thus, it is to be expected that the number of seedlings per foot of row is lower in the furrows than in the alternating beds.

The reduction of seedling numbers in the furrows was greater at CPER (50\% fewer) than at Fort Collins (32\% fewer) because the sandy soil at CPER filled the furrows more quickly than did the loam soil at Fort Collins. The distribution of seedlings in the level-drilled rows on the beds was generally more uniform than in the furrows; this is at least partly attributable to the less precise seed placement in deep-furrow planting and to the uneven deposition of eroded material in the furrows.

\section{Discussion}

Deep-furrow planting is successful with small grains because their large seed size and high seedling vigor permit them to emerge when planted several inches deep in moist soil. Most range grasses have small seeds and cannot emerge if covered as deeply as the small grains. Furrows that are deep enough to provide adequate erosion control and improved soil moisture relations will also permit the seed to be covered too deeply for optimum establishment. However, fair to good establishment has been obtained from furrows about 3 inches deep. Based on this study and on observations in other plantings, the furrows probably do not need to be spaced closer than 24 inches to give adequate erosion control on a well-prepared and firmed seedbed. Stands of grass from seed leveldrilled on the beds between the furrows have been consistently good to excellent. Thus, it should be possible to obtain better overall stands by using the alternate deep-furrow and level seeding system than might be obtained with deep-furrow planting alone, and at the same time, keep erosion to a minimum.

Another method of planting has been suggested for northern Colorado wherein the ground is plowed, immediately formed into ridges by a specially-built heavy roller, and the furrows seeded (Hyder and Bement, 1969). No plowing is attempted until the soil has been wet, but no provision is made for a fallow period. Reported results range from less than 1 to more than 3 plants of crested wheatgrass per foot of row in the furrows when field-scale equipment was used (Hyder, et al., 1971). However, there was no non-ridged (level) 
planting and no planting on fallowed ground with which to compare these results.

The alternate-furrow seeding system has not been tried on field scale plantings. At present, a seeder is being assembled to make larger seedings. These seedings will be made at Fort Collins and CPER on fallowed, tilled, cultipacked seedbeds. It is hoped that by publishing this paper, others will be encouraged to try this technique in order that it may receive a thorough trial. This system does not require expensive or specialized equipment; at present, it is believed that an alternatefurrow seeding can be made with minor modifications to ordinary seeding equipment. The machinery needed for fallowing and packing the seedbed are the same farm implements commonly used for these purposes. However, it is suggested that the planting be confined to strips (Bement et al., 1965) to minimize any serious wind erosion hazard and that alternate-furrow planting not be used for seeding sandhills sites where a protective stubble is required.

\section{Literature Cited}

Bement, R. E., R. D. Barmington, A. C. Everson, L. O. Hylton, JR., AND E. E. Remmenca. 1965. Seeding of abandoned croplands in the central great plains. J. Range Manage. 18:53-59.

HULL, A. C., JR. 1970. Grass seedling emergence and survival from furrows. J. Range Manage. 23:421-424.

Hyder, D. N., AND R. E. BEMENT. 1969. A micro-ridge roller for seedbed modification. J. Range Manage. 22: $54-56$.

Hyder, D. N., A. C. Everson, and R. E. Bement. 1971. Seedling morphology and seeding failures with blue grama. J. Range Manage. 24:287-292.

McGinnies, William J. 1959. The relationship of furrow depth to moisture content of soil and to seedling establishment on a range soil. Agron. J. 51:13-14. 